\title{
Secretory activity of bovine ovarian granulosa cells transfected with sense and antisense insulin-like growth factor (IGF) binding protein-3 and the response to IGF-I, $\mathrm{GH}, \mathrm{LH}$, oxytocin and oestradiol
}

\section{A V Sirotkin, A V Makarevich, M R Corkins ${ }^{1}$, J Kotwica ${ }^{2}$, H B Kwon ${ }^{3}$, J Bulla and L Hetényi}

Research Institute of Animal Production, 94992 Nitra, Slovakia

${ }^{1}$ Indiana University, Riley Hospital for Children, Indianapolis, Indiana 46202, USA

${ }^{2}$ Institute of Animal Production and Food Research, 10-718 Olsztyn-Kortowo, Poland

${ }^{3}$ Department of Biology, Chonnam National University, Kwangju 500-753, Korea

(Requests for offprints should be addressed to A V Sirotkin, Laboratory of Endocrinology, Research Institute of Animal Production, Hlohovská 2, 94992 Nitra, Slovak Republic; Email: sirotkin@vuzv.sk)

\begin{abstract}
The aim of our in vitro experiments was to examine if IGF binding protein (IGFBP)-3 is involved in control of bovine ovarian secretory activity. For this purpose we performed the transfection of bovine granulosa cells with cDNA sense and antisense constructs increasing or inhibiting IGFBP-3 synthesis. The release of IGFBP-3, progesterone, oxytocin, IGF-I and prostaglandins $\mathrm{F}$ (PGF) and $\mathrm{E}$ (PGE) by control and transfected cells was compared. The transfected ovarian cells were cultured with and without bLH $(100 \mathrm{ng} / \mathrm{ml}), \quad \mathrm{bGH} \quad(100 \mathrm{ng} / \mathrm{ml})$, IGF-I (10 ng/ml), oxytocin $(10 \mathrm{ng} / \mathrm{ml})$ and oestradiol-17 $\beta$ (100 $\mathrm{ng} / \mathrm{ml})$. The concentration of IGFBP-3 produced was assessed using ligand and western blotting and secretion of progesterone, oxytocin, IGF-I, PGF and PGE was evaluated using RIA/IRMA techniques.
\end{abstract}

Transfection of cells with the sense IGFBP-3 cDNA construct resulted in the expected increase in IGFBP-3 release, whereas the antisense IGFBP-3 construct induced the expected reduction in IGFBP-3 output. The granulosa cells transfected to overexpress IGFBP-3 had an increase in IGF-I, PGF and PGE release, and a decrease in basal and hormone- or growth factor-induced accumulation of progesterone and oxytocin. The granulosa cells transfected to have reduced IGFBP-3 expression gave primarily significant opposite findings.

The present results suggest the involvement of IGFBP-3 in control of bovine ovarian steroid, peptide hormone, growth factor and prostaglandin release. IGFBP-3 is a physiological stimulator of IGF-I and prostaglandin release and an inhibitor of steroid and peptide hormone output.

Fournal of Molecular Endocrinology (2001) 27, 329-338

\section{INTRODUCTION}

Gonadotrophins (luteinizing hormone (LH) and follicle-stimulating hormone $(\mathrm{FSH})$ ), growth hormone $(\mathrm{GH})$ and oxytocin regulate ovarian functions by altering insulin-like growth factor I (IGF)-I and IGF binding protein (IGFBP) expression (Erickson 1995, Spicer \& Echternkamp 1995, Yoshimura 1998, Schams et al. 1999). In non-ovarian cells, the action of IGF-I is modulated by binding to the IGFBPs that determine the bioavailability of IGF-I in a particular tissue. In addition to IGF-I binding activity, the IGFBPs also have some IGF-Iindependent effects. The most ubiquitous IGFBP present in the majority of tissues is IGFBP-3 (Rajaram et al. 1997, Rechler \& Clemmons 1998). Mammalian ovarian cells have previously been shown to produce both IGF-I and the six classic IGFBPs (Sakal et al. 1992, Spicer \& Echternkamp 1995, Monget et al. 1996, Mihm et al. 1997, Yuan et al. 1998, Schams et al. 1999, Sirotkin \& Makarevich 1999). However, the role that a particular IGFBP exerts in control of ovarian functions remains to be elucidated. 
There are several reports of the direct influence of IGFBPs on ovarian functions. IGFBPs-2, -3 and -5 have inhibitory effects on oocyte maturation, basal FSH and IGF-I-induced ovulation, and secretion of progesterone and oestradiol by human and rat ovaries (Spicer \& Echternkamp 1995, Iwashita et al. 1996, Putowski et al. 1997, Yoshimura 1998). In cultured porcine granulosa cells, IGFBP-3 inhibited basal IGF-I and FSH-induced release of progesterone (Samaras \& Hammond 1995). IGFBP-3 was able to inhibit IGF-I binding, in addition to IGF-I-induced (but not spontaneous) proliferation. IGFBP-3 also inhibited the secretion of progesterone and oestradiol by bovine theca (Spicer $e t$ al. 1997) and granulosa (Spicer \& Chamberlain 1999) cells, but IGF-I was able to prevent these effects. Thus accumulation of IGFBPs in the ovarian structures can, probably primarily through binding of IGF-I, potentially inhibit ovarian proliferation, folliculogenesis, oogenesis and steroidogenesis. To understand the IGF-dependent and -independent effects of IGFBPs, a means of increasing and decreasing IGFBP secretion (without addition of IGF) is therefore necessary. Transfection of ovarian cells with sense and antisense cDNA constructs of an IGFBP can be utilized to examine the effect of increased or decreased IGFBP concentrations on cellular function. This approach has previously been used successfully with non-ovarian cells (Cohen et al. 1993, Corkins et al. 1995, Park et al. 1996).

Ovarian IGFBP production can be stimulated (pig: Grimes et al. 1994, cow: Echternkamp et al. 1994, rat: Putowski et al. 1997) or inhibited (Spicer \& Echternkamp 1995, Mihm et al. 1997) by gonadotrophins. GH can be either a stimulator (cow: Sirotkin \& Makarevich 1999) or an inhibitor (pig: Sirotkin et al. 1998) of IGFBP release by ovarian cells. There are reports on both a stimulatory influence (pig: Grimes et al. 1994) and a lack of effect (pig: Sirotkin et al. 1998) of IGF-I on ovarian IGFBPs. Both a stimulatory effect (cow: Manikkam \& Rajamahedran 1997) and no effect (women: Hamori et al. 1991) of progesterone on this process have been reported. Prostaglandin F (PGF) treatment can either stimulate (cow: Spicer \& Echternkamp 1995) or inhibit (cow: Echternkamp et al. 1994) ovarian IGFBP accumulation. Ovarian IGFBP accumulation can be induced by oestradiol (cow: Mihm et al. 1997) and dibutyryl cAMP (human: Hamori et al. 1991), but not by oxytocin (Sirotkin et al. 1998). Thus the ovarian IGFBPs can be both stimulated and inhibited by various substances (gonadotrophins, GH, IGF-I, steroids, PGF, cAMP etc.) that are known gonadotrophic substances. There are indirect indications that these regulators can affect ovarian functions through alterations in the local IGFBP-3 concentration (Erickson 1995, Spicer \& Echternkamp 1995, Schams et al. 1999, Sirotkin et al. 1998). Nevertheless, the hypothesis of involvement of IGFBPs in the control of ovarian functions and in the mediation of effects of hormones and other ovarian regulators requires direct confirmation.

The first aim of our in vitro experiments was to examine the effects of different gonadotrophic substances on ovarian steroid, peptide hormone and growth factor release, by studying the effects of $\mathrm{LH}$, GH, IGF-I, oxytocin and oestradiol on the release of progesterone, oxytocin, IGF-I and PGF and prostaglandin E (PGE) by bovine granulosa cells. The second aim of our studies was to investigate whether IGFBP-3 is involved in the control of - and mediates the effects of - the gonadotrophic substances mentioned above, on ovarian secretory activity. For this purpose, we performed the transfection of bovine granulosa cells with cDNA constructs increasing or inhibiting IGFBP-3 synthesis. We then compared the release of IGFBP-3, progesterone, oxytocin, IGF-I, PGF and PGE between the control and transfected cells cultured with and without LH, GH, IGF-I, oxytocin and oestradiol.

\section{MATERIALS AND METHODS}

\section{Gene constructs}

The full-length cDNA for rat IGFBP-3 was a gift of Dr S Shimasaki (Whittier Institute for Diabetes and Endocrinology, La Jolla, CA, USA). The 2345-bp EcoRI fragment of the IGFBP-3 cDNA (Shimasaki et al. 1989) was ligated into EcoRIdigested pcDNA3 vector (Invitrogen, San Diego, CA, USA). After ligation, the DNA was used to transform DH5- $\alpha$ Escherichia coli (Gibco-BRL, Gaithersburg, MD, USA) and colonies were selected for ampicillin resistance. Plasmid minipreps were prepared to permit identification of the appropriate sense and antisense orientation of the cDNA insert (Corkins et al. 1995).

\section{Preparation, culture and processing of granulosa cells}

Granulosa cells were collected from the ovaries of Holstein cows (2-4 years of age), during the early and middle follicular phase of the oestrous cycle, after slaughter at a local abattoir. The content of 2-5 mm diameter follicles was aspirated and a suspension of granulosa cells isolated by repeated (three times) centrifugation $(200 \mathrm{~g}, 10 \mathrm{~min})$ and pipetting in fresh incubation medium (DMEM-F-12 1:1 mixture 
(Sigma, St Louis, MO, USA)) supplemented with $10 \%$ bovine fetal serum (Institute of Veterinary Medicine, Brno, Czech Republic) and 1\% antibioticantimycotic solution (Sigma). Afterwards, the cell population was divided into three groups; each group was transfected with gene constructs listed above using the lipofection reagent, DOTAP (Boehringer Mannheim GmbH, Mannheim, Germany), following the instructions of the manufacturer. A mixture of $15 \mu \mathrm{g}$ cDNA, $90 \mu \mathrm{g}$ DOTAP and $6 \times 10^{6}$ cells in $6 \mathrm{ml}$ incubation medium was used for each transfection procedure. Control cells were incubated with DOTAP with $15 \mu \mathrm{g}$ mixed bases (Gibco-BRL) instead of the cDNA constructs. Thereafter, granulosa cells were washed three times in culture medium and precultured at a concentration of $1 \times 10^{6}$ cells $/ \mathrm{ml}$ in $2 \mathrm{ml}$ culture medium in Falcon 24-well plates (Becton Dickinson, Franklin Lakes, NJ, USA) at $37{ }^{\circ} \mathrm{C}$ under $5 \% \mathrm{CO}_{2}$ in humidified air. After 2 days of preculture, the medium was replaced with medium of the same composition including $10 \%$ bovine fetal serum from the Institute of Veterinary Medicine with bovine (b) GH (USDAbGH-B-1, $100 \mathrm{ng} / \mathrm{ml}$ ), bLH (USDA-bLH-B-6, $100 \mathrm{ng} / \mathrm{ml}$; both kindly provided by Dr J A Proudman (USDA Animal Hormone Program, Beltsville, MD, USA), or recombinant IGF-I $(10 \mathrm{ng} / \mathrm{ml})$, synthetic oxytocin $(10 \mathrm{ng} / \mathrm{ml})$ or oestradiol $(100 \mathrm{ng} / \mathrm{ml})$ from Sigma. Control groups in each transfected and non-transfected group contained either no cells (blank control) or cells given no exogenous treatments. The GH, LH, IGF-I, oxytocin and oestradiol used were of immunological grade. Peptide hormones were dissolved in medium immediately before the experiment. Oestradiol was first dissolved in $50 \mu \mathrm{l}$ absolute ethanol and then in incubation medium, so that the content of ethanol did not exceed $0.001 \%$ of the medium. After 2 days of culture, the medium from wells was gently aspirated and frozen at $-18{ }^{\circ} \mathrm{C}$ until required for ligand blotting, western blotting and RIA. After culture, cells were gently scraped and pipetted to break the cell clumps. Afterwards, cell numbers and viability were determined by Trypan blue staining and counting in a haemocytometer. No statistically significant differences in these indices between control and experimental groups were observed.

\section{Immunoassay}

Concentrations of hormones in $25-100 \mu \mathrm{l}$ incubation medium were determined by RIA/IRMA. IGF-I and progesterone were assayed using RIA/IRMA kits from DSL (Webster, TX, USA) according to the instructions of the manufacturer. Oxytocin, PGF and PGE were measured using our RIA described previously (Cetta et al. 1982, Kotwica \& Skarzinski 1993, Chang et al. 1995). The characteristics of these assays are presented in Table 1.

\section{Protein gel electrophoresis and immunoblotting}

Samples of medium $(20 \mu \mathrm{l})$ were mixed with $10 \mu \mathrm{l}$ electrophoretic buffer $(0.0625 \mathrm{M}$ Tris base, $2 \%$ SDS, 10\% glycerol, 5\% 2-mercaptoethanol, 0.003\% bromophenol blue; all from Sigma) and boiled at $95{ }^{\circ} \mathrm{C}$ for $3 \mathrm{~min}$ and subjected to SDS-PAGE in $4 \%$ and $10 \%$ polyacrylamide in stacking and resolving gels respectively at $25 \mathrm{~mA}$ constant current, according to the method of Laemmli (1970). The samples were then transferred for $1 \mathrm{~h}$ to nitrocellulose membranes (enhanced chemiluminescence (ECL) Hybond, Amersham International plc, Little Chalfont, Bucks, UK) using a semi-dry trans-blotter (Bio-Rad Labs, Richmond, VA, USA). Endogenous peroxidase in samples was quenched by incubation in $3 \% \mathrm{H}_{2} \mathrm{O}_{2}$ for $15 \mathrm{~min}$. Non-specific binding of antiserum was prevented by blocking with $5 \%$ blotqualified BSA (Amersham) in TTBS $(20 \mathrm{nM}$ Tris base, $137 \mathrm{nM} \mathrm{NaCl}, 0 \cdot 1 \%$ Tween 20). Blocked membranes were probed with rabbit polyclonal antibody against human recombinant IGFBP-3 (Upstate Biotechnology Inc., Lake Placid, NY, USA; dilution 1:2000). This antibody has high specificity for IGFBP-3 and only slight $(0 \cdot 1-0 \cdot 5 \%)$ cross reactivity for IGFBPs-2, -4 and -5 ; cross reactivity with IGFBP-1 was $2 \%$. Preliminary western blotting and immunocytochemical data showed the ability of this antiserum to detect IGFBP-3 not only in human, but also in rat, bovine and porcine biological fluids (data not shown, see also Fig. 2). Membranes were then incubated with a secondary horseradish peroxidaseconjugated antirabbit $\operatorname{Ig} G$ antibody and visualized using ECL detection reagents and ECL Hyper-film (all from Amersham). Incubation medium without cells was used as a negative control. Rat serum samples (Transduction Laboratories, Lexington, CT, USA) and fluid aspirated from bovine ovarian follicles $2-5 \mathrm{~cm}$ in diameter and porcine ovarian follicles $2-3 \mathrm{~cm}$ in diameter (separated from cells by centrifugation as described above) were used as positive controls. The molecular weights of fractions were evaluated using a molecular weight calibration kit (14·4-94.0 kDa; Serva, Heidelberg, Germany).

\section{Protein gel electrophoresis and ligand blotting}

IGFBP-3 protein was compared by ligand blot analysis as described by Hossenlopp et al. (1986) and modified by McCusker et al. (1988). Briefly, 
TABLE 1. Characteristics of immunoassays used in experiments

\begin{tabular}{|c|c|c|c|c|}
\hline & \multirow[b]{2}{*}{$\begin{array}{l}\text { Specificity of assay } \\
\text { (cross-reactivity of antiserum) }\end{array}$} & \multirow{2}{*}{$\begin{array}{l}\text { Sensitivity } \\
\text { of assay } \\
(\mathrm{ng} / \mathrm{ml})\end{array}$} & \multicolumn{2}{|c|}{$\begin{array}{l}\text { Coefficient of } \\
\text { variation }(\%)\end{array}$} \\
\hline & & & $\begin{array}{l}\text { Intra- } \\
\text { assay }\end{array}$ & $\begin{array}{l}\text { Inter } \\
\text { assay }\end{array}$ \\
\hline \multicolumn{5}{|l|}{ Assay } \\
\hline IGF-I & $\begin{array}{l}<0 \cdot 01 \% \text { to IGF-II, } \\
\text { insulin, proinsulin, } \\
\text { EGF, bGH, oxytocin, } \\
\text { progesterone, oestradiol }\end{array}$ & $0 \cdot 027$ & $<3.4$ & $<8 \cdot 2$ \\
\hline Progesterone & $\begin{array}{l}<0 \cdot 001 \% \text { to cortisol, } \\
\text { corticosterone, } \\
\text { cortisol, androstenediol, } \\
\text { pregnenolone, } \\
\text { oestradiol, testosterone }\end{array}$ & $0 \cdot 12$ & $<13 \cdot 1$ & $<8 \cdot 0$ \\
\hline Oxytocin & $\begin{array}{l}<0 \cdot 01 \% \text { to arginine-vasopressin, } \\
\text { lysine-vasopressin, } \\
\text { arginine-vasotocin, } \\
\text { somatostatin }\end{array}$ & $0 \cdot 003$ & $<10 \cdot 5$ & $<5 \cdot 6$ \\
\hline \multirow[t]{2}{*}{ PGF } & $\begin{array}{l}<0 \cdot 01 \% \text { to PGA-1, PGA-2, } \\
\text { PGB-1, PGB-2 } \\
<0 \cdot 1 \% \text { to PGE-1, PGE-2, } \\
66 \% \text { to PGF- } 1\end{array}$ & & & \\
\hline & $100 \%$ to $\mathrm{PGF}-2$ & $0 \cdot 005$ & $<7 \cdot 7$ & $<4 \cdot 3$ \\
\hline \multirow[t]{8}{*}{ PGE } & $<28.0 \%$ to $\mathrm{PGA}-1$ & & & \\
\hline & $<7 \cdot 0 \%$ to $\mathrm{PGA}-2$ & & & \\
\hline & $<0.6 \%$ to $\mathrm{PGB}-1$ & & & \\
\hline & $<1 \cdot 4 \%$ to $\mathrm{PGB}-2$ & & & \\
\hline & $<5 \cdot 0 \%$ to $\mathrm{PGF}-1$ & & & \\
\hline & $<1.5 \%$ to $\mathrm{PGF}-2$ & & & \\
\hline & $165 \%$ to $\mathrm{PGE}-1$ & & & \\
\hline & $100 \%$ to $\mathrm{PGE}-2$ & $0 \cdot 015$ & $<7 \cdot 5$ & $<4 \cdot 0$ \\
\hline
\end{tabular}

EGF, epidermal growth-factor; PGA, PGB, prostaglandins A and B.

$80 \mu \mathrm{l}$ conditioned culture medium or control serum (human and fetal bovine) were mixed with $80 \mu \mathrm{l}$ electrophoretic buffer mentioned above, and this mixture was electrophoresed in $12.5 \%$ polyacrylamide gels in the presence of SDS under non-reducing conditions (Laemmli 1970). After electroblotting onto $0.05 \mu \mathrm{m}$ BA-75 nitrocellulose (Schleicher and Schuell, Keene, NH, USA), the blots were probed with $\left.{ }^{125} \mathrm{I}\right] \mathrm{IGF}-\mathrm{II}$. Signal intensities for radioactive bands on each blot were quantified by use of a PhosphorImager (Molecular Dynamics, Sunnyvale, CA, USA) with the results reported as arbitrary units.

\section{Statistics}

Each experimental group was represented by four culture wells. Assays of hormone and growth factor concentrations in conditioned medium were performed in duplicate. The quantitative data shown are the means of three experiments on granulosa cells from a separate pool of ovaries harvested from 20 animals. The western and ligand blots shown were obtained in separate experiments: one each, repeated twice. In the RIA/IRMA assays, the value of the blank control was subtracted from the value determined in the conditioned medium to exclude any non-specific background $(0-26 \%$ of total values). The secretion rates were calculated per $1 \times 10^{6}$ viable cells at the end of culturing/day. Significant differences between the experiments were evaluated by a two-way ANOVA. The treatment effects from the experimental and control groups were compared by Duncan's multiple range test. Differences from controls with $P<0.05$ were considered significant.

\section{RESULTS}

The presence of IGFBPs in culture medium conditioned by bovine granulosa cells was demonstrated by ligand blotting (Fig. 1). The main IGF-binding protein expressed had a relative molecular weight of $45 \mathrm{kDa}$, characteristic of IGFBP-3. Lipofection of granulosa cells with the 


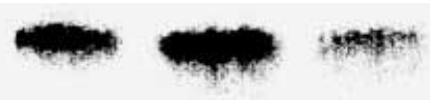

$1 \quad 2 \quad 3 \quad 4$

FIGURE 1. Ligand blotting of culture medium conditioned by bovine granulosa cells. Lane 1: control cells (transfection with mixed bases); lane 2: cells transfected with sense IGFBP-3 cDNA construct; lane 3: cells transfected with antisense IGFBP-3 cDNA construct; lane 4: negative control (medium cultured without cells).

sense IGFBP-3 cDNA construct resulted in an increase in expression of IGFBP-3 in the conditioned medium. As presented in Fig. 1, the IGFBP-3 band increased from 172611 arbitrary units in the control cells to 222437 arbitrary units in the transfected cells. In contrast, transfection with an antisense IGFBP-3 construct markedly decreased the IGFBP-3 band to an expression of 131842 arbitrary units.

The presence of IGFBP-3 in bovine granulosa cell conditioned medium was confirmed also by western blotting (Fig. 2). The $45 \mathrm{kDa}$ band, which binds antiserum against IGFBP-3, was observed in rabbit serum and bovine (but not porcine) follicular fluid (positive control), and in conditioned medium after culture of control bovine granulosa cells (transfected with mixed bases), but not in cells transfected with the IGFBP-3 antisense construct or in medium cultured without cells (negative control).

Results of the RIA/IRMAs of the conditioned medium showed that bovine granulosa cells are able to secrete significant amounts of IGF-I, oxytocin, progesterone, PGF and PGE. The assays also showed that release of these substances is altered by transfection of cells with constructs altering IGFBP-3 production, by exogenous hormones and by IGF-I (Figs $3-7$ ).

Progesterone release (Fig. 3) by control cells was significantly decreased by GH, oestradiol, LH and oxytocin treatments, whereas IGF-I dramatically increased it. Transfection of cells with the IGFBP-3 sense construct slightly decreased basal progesterone output and significantly reduced IGF-Iinduced progesterone release, but not progesterone

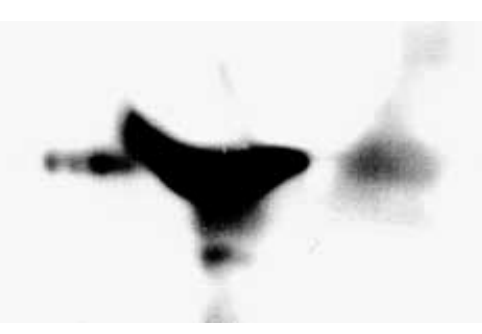

$\begin{array}{lllllll}1 & 2 & 3 & 4 & 5 & 6\end{array}$

FIGURE 2. Western immunoblotting for IGFBP-3 culture medium conditioned by bovine granulosa cells. Lane 1: negative control (medium cultured without cells); lane 2: cells transfected with antisense IGFBP-3 cDNA construct; lane 3: control cells (transfection with mixed bases); lane 4: positive control I (normal rabbit serum); lane 5: positive control II (bovine ovarian follicular fluid); lane 6: positive control III (porcine ovarian follicular fluid).

secretion under the influence of inhibitors $(\mathrm{GH}$, oestradiol, LH, oxytocin). Introduction of the IGFBP-3 antisense construct resulted in significant increases in basal and oestradiol-inhibited progesterone release, but did not influence the stimulatory effect of peptide hormones on progesterone output.

IGF-I release (Fig. 4) in these experiments was not substantially affected by exogenous GH (its stimulatory influence was statistically insignificant), but oestradiol, LH and oxytocin significantly augmented it. Transfection of cells with the IGFBP-3 sense construct increased basal IGF-I release, but prevented the stimulatory effects of other hormones. Moreover, oestradiol and LH in these cells inhibited IGF-I output. Basal IGF-I release by cells transfected with the IGFBP-3 antisense construct did not significantly differ from the initial concentrations in control cells, but was significantly lower than in cells transfected with the IGFBP-3 sense construct. Moreover, transfection of cells with IGFBP-3 antisense construct significantly inhibited IGF-I release in the presence of $\mathrm{GH}$ and oestradiol, but not of other hormones: significant differences between respective groups of transfected and control cells (transfected with mixed bases) were found.

Oxytocin release (Fig. 5) in control cells was not affected by GH, IGF-I or oxytocin, but oestradiol significantly reduced it. Cells transfected with the IGFBP-3 sense construct produced significantly less oxytocin than control cells. Furthermore, in treated cells transfected with the IGFBP-3 sense construct, oxytocin release was reduced in the 


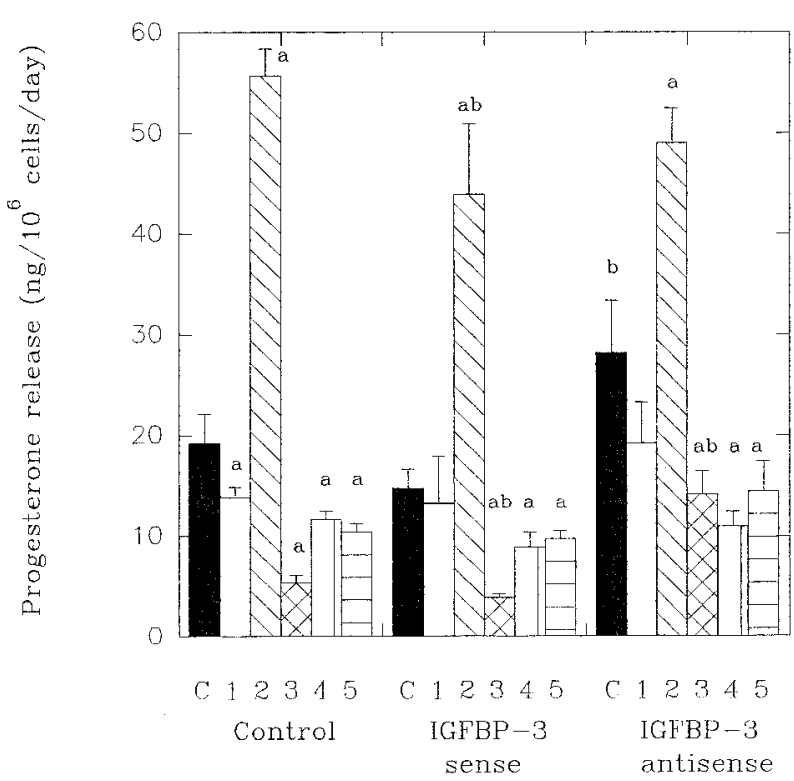

FIGURE 3. Progesterone released by cultured bovine granulosa cells. Effect of hormones and growth factor on progesterone release by cultured bovine granulosa cells not transfected (transfection with mixed bases; Control) and transfected with sense (IGFBP-3 sense) and antisense (IGFBP-3 antisense) IGFBP-3 cDNA constructs. C, control (cells cultured without exogenous hormones or growth factor); 1 , cells cultured with bGH (100 ng/ml medium); 2, cells cultured with IGF-I $(10 \mathrm{ng} / \mathrm{ml}) ; 3$, cells cultured with oestradiol $(100 \mathrm{ng} / \mathrm{ml})$; 4 , cells cultured with bLH $(100 \mathrm{ng} / \mathrm{ml}) ; 5$, cells cultured with oxytocin $(10 \mathrm{ng} / \mathrm{ml})$. Values are means \pm s.E.M.

Significant differences $(P<0 \cdot 05)$ : ${ }^{a}$ between cells cultured with and without exogenous hormones or growth factors, between respective groups of transfected and not transfected cells.

IGF-I-treated and increased in the LH-treated groups. No significant differences in basal oxytocin release between the IGFBP-3 antisense-transfected and control groups was detected, although in the control group oestradiol inhibited oxytocin, whereas in the IGFBP-3 antisense transfected cells oestradiol increased oxytocin release over both controls (without oestradiol and without transfection).

PGF release (Fig. 6) in control cells was only at the limit of sensitivity of the assays; however, it was increased several-fold by $\mathrm{GH}$, oestradiol, $\mathrm{LH}$ and oxytocin, but not by IGF-I treatment. IGFBP-3 sense construct transfected cells had significantly stimulated basal, GH- and IGF-I-induced PGF output, but not PGF release, in the presence of other hormones. Transfection of cells with IGFBP-3 antisense construct did not significantly affect basal PGF accumulation, but it dramatically reduced hormoneinduced PGF release: instead of stimulation under the

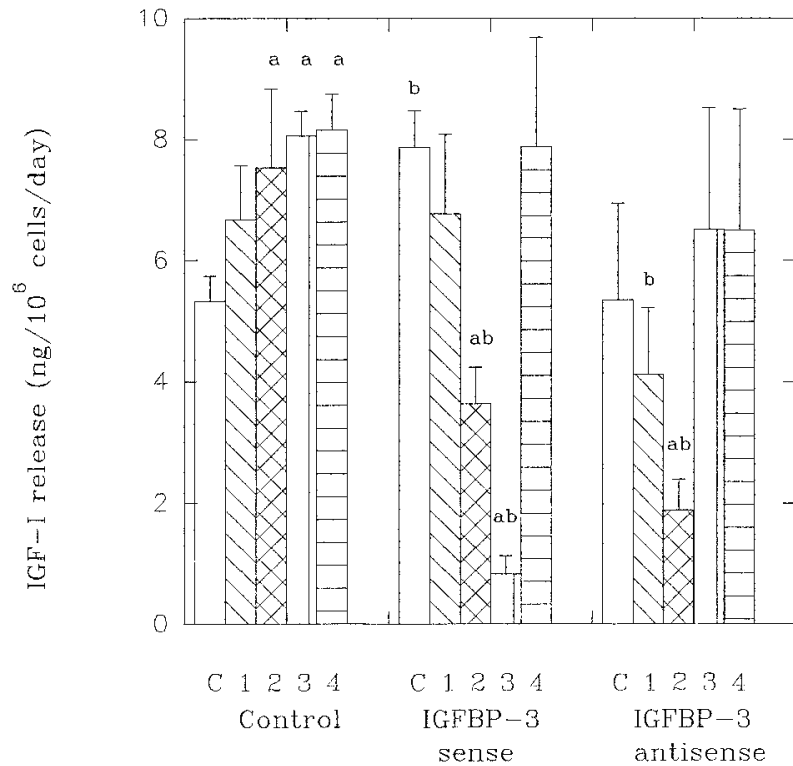

FIGURE 4. IGF-I released by cultured bovine granulosa cells. Effect of hormones on IGF-I release by cultured bovine granulosa cells not transfected (transfection with mixed bases; Control) and transfected with sense (IGFBP-3 sense) and antisense (IGFBP-3 antisense) IGFBP-3 cDNA constructs. $\mathrm{C}$, control (cells cultured without exogenous hormones); 1, cells cultured with bGH (100 ng/ml medium); 2, cells cultured with oestradiol $(100 \mathrm{ng} / \mathrm{ml})$; 3 , cells cultured with bLH $(100 \mathrm{ng} / \mathrm{ml}) ; 4$, cells cultured with oxytocin $(10 \mathrm{ng} / \mathrm{ml})$. Values are means \pm s.E.M. Significant differences $(P<0 \cdot 05)$ : ${ }^{a}$ between cells cultured with and without exogenous hormones or growth factors, between respective groups of transfected and not transfected cells.

influence of hormones (as in control and IGFBP-3 sense and treated cells), PGF accumulation was blocked at the minimal detectable level.

PGE release (Fig. 7) in control cells in the absence of hormone stimulation was low, near the limit of sensitivity of the assay. GH, oestradiol and oxytocin, but not IGF-I or LH, dramatically enhanced PGE expression. Transfection of cells with IGFBP-3 sense construct significantly increased the basal, IGF-Iand LH-induced PGE release, but not its accumulation, in the presence of other hormones. The IGFBP-3 antisense transfected cells were completely or partially blocked from the stimulatory influence of all hormones on PGE output.

\section{DISCUSSION}

The present data suggest that the culture of normal and transfected granulosa cells used in our experiments is suitable for maintenance of their viability and secretory activity, and for studying 

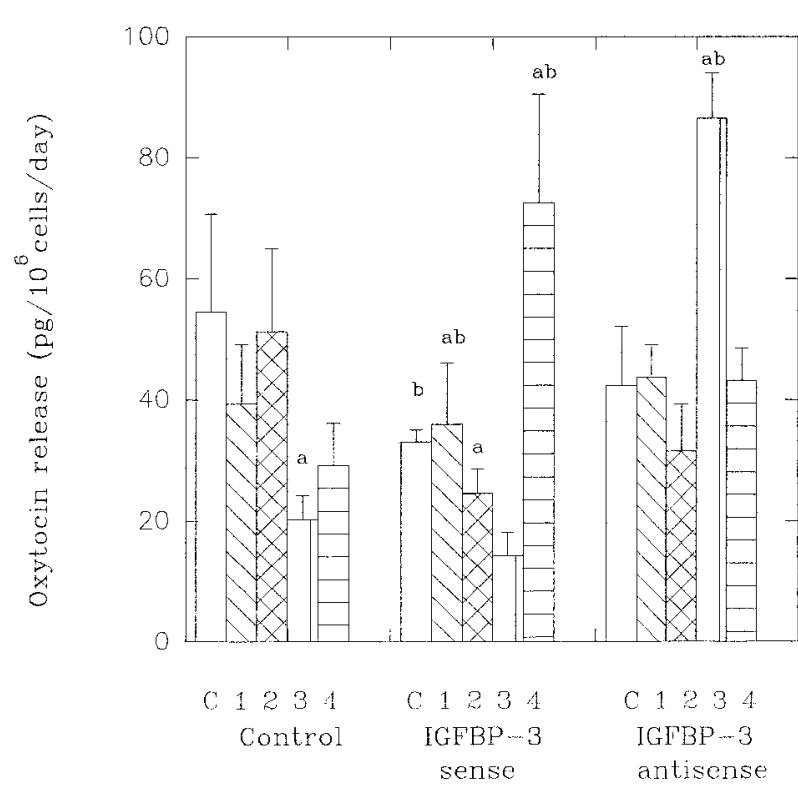

FIGURE 5. Oxytocin released by cultured bovine granulosa cells. Effect of hormones and growth factor on oxytocin release by cultured bovine granulosa cells not transfected (transfection with mixed bases; Control) and transfected with sense (IGFBP-3 sense) and antisense (IGFBP-3 antisense) IGFBP-3 cDNA constructs. C, control (cells cultured without exogenous hormones and growth factor); 1, cells cultured with bGH $(100 \mathrm{ng} / \mathrm{ml}$ medium); 2, cells cultured with IGF-I $(10 \mathrm{ng} / \mathrm{ml})$; 3 , cells cultured with oestradiol $(100 \mathrm{ng} / \mathrm{ml}) ; 4$, cells cultured with bLH $(100 \mathrm{ng} / \mathrm{ml})$. Values are means \pm s.E.M. Significant differences $(P<0 \cdot 05)$ : abetween cells cultured with and without exogenous hormones or growth factors, b between respective groups of transfected and not transfected cells.

the effect of transfection with cDNA constructs mentioned above. This confirms our previous observations (Makarevic \& Sirotkin 1996, Sirotkin et al. 1998) of the usefulness of serum-supplemented medium for stimulation of basal ovarian secretion and response. Nevertheless, in interpreting the data obtained using serum-supplemented medium, it should be kept in mind that, despite the use of blank controls, serum (which can contain hormones, growth factors and IGFBPs) may affect basal secretory activity and responses of cells, and the metabolism of exogenous and endogenous substances.

Our observations confirm previous reports (Shemesh 1979, Sakal et al. 1992, Sirotkin \& Nitray 1994, Spicer \& Echternkamp 1995, Makarevich \& Sirotkin 1996, Sirotkin 1996) of the production of IGFBP-3, IGF-I, oxytocin, progesterone and PGF by cultured bovine granulosa cells. The amounts of these substances produced by cells after the transfection procedures in our experiments are comparable to

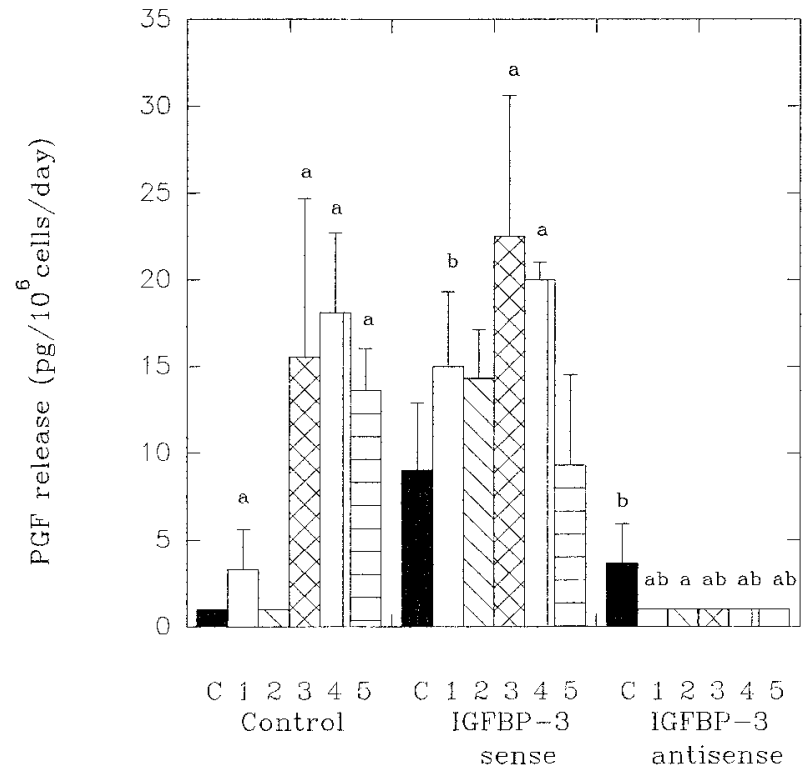

FIGURE 6. PGF released by cultured bovine granulosa cells. Effect of hormones and growth factor on PGF release by cultured bovine granulosa cells not transfected (transfection with mixed bases; Control) and transfected with sense (IGFBP-3 sense) and antisense (IGFBP-3 antisense) IGFBP-3 cDNA constructs. C, control (cells cultured without exogenous hormones and growth factor); 1, cells cultured with bGH (100 ng/ml medium); 2, cells cultured with IGF-I (10 ng/ml); 3 , cells cultured with oestradiol $(100 \mathrm{ng} / \mathrm{ml}) ; 4$, cells cultured with bLH (100 ng/ml); 5, cells cultured with oxytocin $(10 \mathrm{ng} / \mathrm{ml})$. Values are means \pm s.E.M.

Significant differences $(P<0 \cdot 05)$ : ${ }^{a}$ between cells cultured with and without exogenous hormones or growth factors, between respective groups of transfected and not transfected cells.

those described in non-transfected bovine granulosa cells. Ovarian PGE production has been demonstrated previously in other species (Cetta et al. 1982, Chang et al. 1995, Sirotkin et al. 1998), but this seems to be the first demonstration of the release of this substance by bovine ovarian cells.

Our results support previous evidence of the involvement of GH (Sirotkin \& Nitray 1994, Spicer \& Echternkamp 1995, Makarevich \& Sirotkin 1996, Sirotkin 1996, Sirotkin \& Makarevich 1999), IGF-I (Erickson 1995, Spicer \& Echternkamp 1995, Sirotkin et al. 1998), LH, oestradiol (Wathes 1989, Erickson 1995, Spicer \& Echternkamp 1995, Sirotkin et al. 1998) and oxytocin (Wathes 1989, Sirotkin et al. 1998) in the control of the secretion of IGF-I, oxytocin, steroids and prostaglandins by mammalian ovarian cells. This is the first evidence of the involvement of oxytocin, IGF-I and steroids 


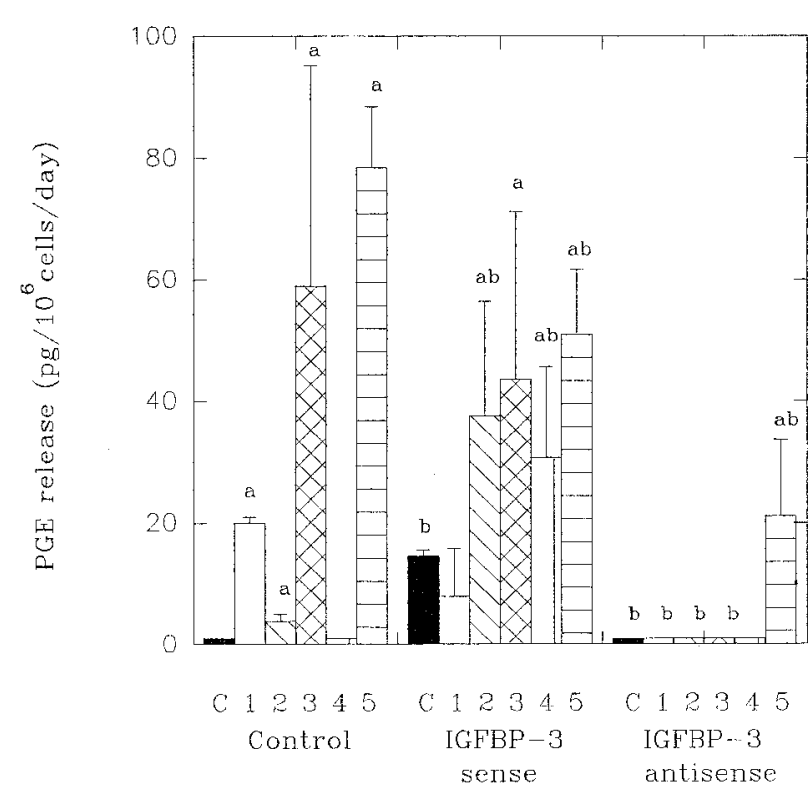

FIGURE 7. PGE released by cultured bovine granulosa cells. Effect of hormones and growth factor on PGE release by cultured bovine granulosa cells not transfected (transfection with mixed bases; Control) and transfected with sense (IGFBP-3 sense) and antisense (IGFBP-3 antisense) IGFBP-3 cDNA constructs. C, control (cells cultured without exogenous hormones and growth factor); 1, cells cultured with bGH (100 ng/ml medium); 2, cells cultured with IGF-I $(10 \mathrm{ng} / \mathrm{ml})$; 3 , cells cultured with oestradiol $(100 \mathrm{ng} / \mathrm{ml}) ; 4$, cells cultured with bLH $(100 \mathrm{ng} / \mathrm{ml}) ; 5$, cells cultured with oxytocin $(10 \mathrm{ng} / \mathrm{ml})$. Values are means \pm s.E.M.

Significant differences $(P<0 \cdot 05)$ : ${ }^{a}$ between cells cultured with and without exogenous hormones or growth factors, between respective groups of transfected and not transfected cells.

in the control of prostaglandin release by bovine ovarian cells.

In bovine (Echternkamp et al. 1994, Spicer \& Echternkamp 1995, Mihm et al. 1997, Khatir et al. 1997, Yuan et al. 1998), ovine (Spicer \& Echternkamp 1995, Monget et al. 1996), porcine (Guthrie et al. 1995), murine (Wandji et al. 1998) and human (Yoshimura 1998) follicles there is a correllation between the IGFBPs-1, $-2,-4$ and -5 (but not IGFBP-3) concentrations in follicular fluid and follicular size, the expression of atresia, and the ability of follicular fluid to support oocyte maturation. This is an indirect indication of the involvement of the IGFBPs in these processes. However, IGFBP-3 concentrations in the follicular fluid during follicular growth and atresia change little or not at all. Therefore, these processes are associated with or regulated by (or both) changes in the relative proportions of IGFBPs-2, -4 or -5 to that of IGFBP-3.

Results of our ligand (Fig. 1) and western (Fig. 2) blotting confirm the previous reports (Spicer \& Echternkamp 1995, Mihm et al. 1997, Khatir et al. 1997, Schams et al. 1999, Sirotkin \& Makarevich 1999) of the release of IGFBP-3 by bovine ovarian cells and do not corroborate other reports (Echternkamp et al. 1994, Yuan et al. 1998) of no or minimal IGFBP-3 production by these cells. Furthermore, identification of IGFBP-3 in bovine and rabbit, but not in porcine material using immunoblotting in our experiments (Fig. 2) suggests that substantial differences exist in the immunological properties of IGFBP-3 in different species. Our studies also confirmed that the transfection of cultured granulosa cells with an IGFBP-3 sense construct results in an increase in IGFBP-3 production, and that the related IGFBP-3 antisense construct inhibited IGFBP-3 production. These are the first data on the role of ovarian IGFBP-3 in mammals, utilizing a transfection approach to alter the normal levels of expression.

The ovarian cell transfection altered not only IGFBP-3 expression, but also basal IGF-I, oxytocin, progesterone, PGF and PGE concentrations, as observed in our experiments. These findings suggest the involvement of IGFBP-3 in control of the release of these substances. Sense IGFBP-3 cDNA transfection resulted in an increase in basal and hormone-induced IGF-I, PGF and PGE concentrations and a decrease in progesterone and oxytocin concentrations, in cell-conditioned medium. The IGFBP-3 antisense transfection had an opposite effect, at least in the case of progesterone and IGF-I release. Differences between IGFBP-3 sense and antisense cultures were more pronounced than those between transfected and control cells. These data suggest that IGFBP-3 can be a physiological stimulator of IGF-I and prostaglandin release, and an inhibitor of steroid and peptide hormone release, by bovine ovarian granulosa cells. A possible mechanism of action is the protective effect of IGFBP-3 for IGF-I: IGFBP-3 binds IGF-I to prevent its catabolism that has been observed in non-ovarian cells (Rajaram et al. 1997, Rechler \& Clemmons 1998). The present observations of a change in basal progesterone release in the transfected cells are in agreement with a previous report by Samaras \& Hammond (1995) of the antisteroidogenic action of exogenous IGFBP-3 treatment on porcine ovarian cells. This is the first evidence we know of the involvement of IGFBP-3 in mammalian ovarian peptide hormone, growth factor and prostaglandin release.

Our observations indicate that IGFBP-3 can affect not only basal secretory activity, but also the 
response of ovarian cells to extra- and intraovarian regulators - gonadotrophin, GH, IGF-I, peptide and steroid hormones. The transfection-induced increase in IGFBP-3 was associated with inhibition of the effect of IGF-I on progesterone and oxytocin, and an augmentation of the influence of IGF-I on PGE, but not on PGF, release. In contrast, the transfection-induced decrease in IGFBP-3 production was associated with prevention of the effect of IGF-I on PGF and PGE, but not on other substances. The ability of IGFBP-3 both to inhibit and to promote IGF-I action may be explained by its ability to bind IGF-I, to reduce its bioavailability but also prevent its biodegradation. However, a possible IGF-I-independent effect of IGFBP-3 should not be excluded. For example, antisense IGFBP-3 transfection in our experiments did not affect basal IGF-I concentration, but prevented the effects of several hormones on the release of IGF-I, oxytocin, PGF and PGE. Moreover, an increase in basal IGF-I secretion induced by the transfection with the IGFBP-3 sense construct was not always associated with a change in the response of cells to hormonal treatments. Thus both an IGF-Idependent and an IGF-I-independent action of IGFBP-3 can be hypothesised.

Reports on the influence of various hormones and IGF-I on the ovarian release of IGFBP-3 (Hamori et al. 1991, Echternkamp et al. 1994, Spicer \& Echternkamp 1995, Manikkam \& Rajamahedran 1997, Mihm et al. 1997, Putowski et al. 1997, Sirotkin et al. 1998, Sirotkin \& Makarevich 1999) indirectly indicate that IGFBP-3 might be a potential mediator of the action of these substances on reproductive processes. Reduced expression of IGFBP-3, first used in our experiments, provides new evidence for this hypothesis: transfectionmediated inhibition of IGFBP-3 release almost completely blocked the effects of hormones and growth factors on PGF and PGE release by bovine ovarian cells. However, inhibition of IGFBP-3 failed to prevent fully the action of exogenous substances on IGF-I, oxytocin and progesterone release. This could be due to only a partial blockade of IGFBP-3 release by the transfected cells, so that the IGFBP-3 concentration was sufficiently decreased to block completely the responses of PGF and PGE, but not low enough to inhibit the responses of IGF-I, oxytocin and oestradiol. These observations suggest differences between the ovarian substances in response or sensitivity to IGFBP-3 action and, consequently, a different role for IGFBP-3 in their control. Nevertheless, they suggest that ovarian IGFBP-3 can be a potential mediator of hormonal and IGF-I actions, at least on ovarian prostaglandin production.
The significance and the mechanisms of IGFBP-3 action on the ovary require further detailed studies. Nevertheless, our approach strongly suggested the involvment of IGFBP-3 in the control of ovarian secretory activity - that is, of the release of steroid, peptide hormones, growth factor and prostaglandins. The precise mechanism of IGFBP-3 action probably varies, depending on the particular biological process and its regulation, but the role of IGFBP-3 as a regulator of ovarian secretory activity and as a mediator of the action of hormones and IGF-I on the ovary via IGF-I-dependent or IGF-I-independent (or both) mechanisms are suggested.

\section{ACKNOWLEDGEMENTS}

We express our gratitude to Dr S Shimasaki (The Whittier Institute for Diabetes and Endocrinology, La Jolla, CA, USA) for the gift of cDNA for IGFBP-3, Dr J A Proudman (USDA Animal Hormone Program, Beltsville, USA) for kindly providing the bGH and bLH, Dr G Kotwica (University of Agriculture and Technology, Olsztyn, Poland) for the donation of antiserum against oxytocin, and Mrs T Civáňová, K Tothová, M Blahová, and B Ustianovska for technical assistance.

\section{REFERENCES}

Cetta F \& Goetz FWM 1982 Ovarian and plasma prostaglandin $\mathrm{E}$ and $\mathrm{F}$ levels in brook trout (Salvelinus fontinalis) during pituitary-induced ovulation. Biology of Reproduction 27 1216-1221.

Chang KJ, Kim JW, Lee J, Im W-B, Kwon HB \& Schuetz AW 1995 Prostaglandin production and ovulation during exposure of amphibian ovarian follicles to gonadotropin or phorbol ester in vitro. General and Comparative Endocrinology 100 257-266.

Cohen P, Lamson G, Okajima T \& Rosenfeld RG 1993 Transfection of the insulin-like growth factor binding protein-3 gene into Balb/c fibroblasts inhibits cellular growth. Molecular Endocrinology 7 380-386.

Corkins MR, Vanderhoof JA, Caruso NM, Hrbek MJ, Schaffer BS, Slentz DH, McCusker RH \& MacDonald RG 1995 Growth stimulation by transfection of intestinal epithelial cells with an antisense insulin-like growth factor binding protein-2 construct. Biochemical and Biophysical Research Communications 211 707-713.

Echternkamp SE, Howard HJ, Roberts AJ, Grizzle J \& Wise T 1994 Relationships among concentrations of steroids, insulin-like growth factor-I, and insulin-like growth factor binding proteins in ovarian follicular fluid of beef cattle. Biology of Reproduction 51 971-981.

Erickson GF 1995 The ovarian connections. In Reproductive Endocrinology, Surgery and Technology, pp 1141-1160. Eds E Adashi, J A Rock \& Z Rosenwars. New York: Raven Press. Grimes RW, Gutherie HD \& Hammond JM 1994 Insulin-like growth factor-binding protein-2 and -3 are correlated with 
atresia and preovulatory maturation in the porcine ovary. Endocrinology 135 1996-2000.

Guthrie HD, Grimes RW \& Hammond JM 1995 Changes in insulin-like growth factor-binding protein-2 and -3 in follicular fluid during atresia of follicles grown after ovulation in pigs. Fournal of Reproduction and Fertility 104 225-230.

Hamori M, Blum WF, Torok A, Stehle R, Waibel E, Cledon P \& Ranke MB 1991 Immunoreactive insulin-like growth factor binding protein-3 in the culture of human luteinized granulosa cells. Acta Endocrinologica 124 685-691.

Hossenlopp P, Seurin D, Segovia-Quinson B, Hardouin S \& Binoux M 1986 Analysis of serum insulin-like growth factor binding proteins using western blotting: use of the method for titration of the binding proteins and competitive binding studies. Analytical Biochemistry 154 138-143.

Iwashita M, Kudo Y, Yoshimura Y, Adashi T, Katayama E \& Takeda Y 1996 Physiological role of insulin-like growth factor binding protein- 4 in human folliculogenesis. Hormone Research 46 (Suppl) 31-36.

Khatir H, Carolan C, Lonergan P \& Mermillod P 1997 Characterization of calf follicular fluid and its ability to support cytoplasmic maturation of cow and calf oocytes. Fournal of Reproduction and Fertility 111 267-275.

Kotwica J \& Skarzinski D 1993 Influence of oxytocin removal from the corpus luteum on secretory function and duration of the estrous cycle in cattle. Fournal of Reproduction and Fertility 97 411-417.

Laemmli UK 1970 Cleavage and structure of proteins during the assembly of the head of bacteriophage T4. Nature 227 680-685.

McCusker RH, Champion DR \& Clemmons DR 1988 The ontogeny and regulation of a $31,000 \mathrm{M}_{\mathrm{r}}$ insulin-like growth factor/somatomedin (IGF) binding protein in fetal porcine plasma and sera. Endocrinology 122 3071-3079.

Makarevic A \& Sirotkin A 1996 Production of insulin-like growth factor type I (IGF-I) by bovine ovarian cells in vitro. Fournal of Farm Animal Sciences 2 61-68.

Manikkam M \& Rajamahedran R 1997 Progesterone-induced atresia of the proestrous dominant follicle in the bovine ovary: changes in diameter, insulin-like growth factor systém, aromatase activity, steroid hormones, and apoptotic index. Biology of Reproduction 57 580-587.

Mihm M, Good TE, Ireland JL, Ireland JJ, Knight PG \& Roche JF 1997 Decline in serum follicle-stimulating hormone concentrations alters key intrafollicular growth factors involved in selection of the dominant follicle in heifers. Biology of Reproduction 57 1328-1337.

Monget P, Besnard A, Huet C, Pisselet C \& Monniaux D 1996 Insulin-like growth factor-binding proteins and ovarian folliculogenesis. Hormone Research 45 211-217.

Park JHY, Corkins MR, Vanderhoof JA, Caruso NM, Hrbek MJ, Schaffer BS, Slentz DH, McCusker RH \& MacDonald RG 1996 Expression of insulin-like growth factor-II and insulin-like growth factor binding proteins during Caco-2 cell proliferation and differentiation. Fournal of Cellular Physiology 166 396-406.

Putowski L, Rohan RM, Choi DS, Scherzer WJ, Ricciarelli E, Mordacq J, Mayo KE \& Adashi EY 1997 Rat ovarian insulin-like growth factor binding protein-4: a hormonedependent granulosa cell-derived antigonadotropin. Fournal of the Society for Gynecological Investigations 4 144-151.

Rajaram S, Baylink DJ \& Mohan S 1997 Insulin-like growth factor-binding proteins in serum and other biological fluids: regulation and functions. Endocrine Reviews 18 801-831.
Rechler MW \& Clemmons DR 1998 Regulatory actions of insulin-like growth factor-binding proteins. Trends in Endocrinology and Metabolism 9 176-183.

Sakal E, Gertler A, Afialo L \& Meidan R 1992 Characterization of insulin-like growth factor binding proteins secreted by cultured bovine theca and granulosa cells. Molecular and Cellular Endocrinology 90 39-46.

Samaras SE \& Hammond JM 1995 Insulin-like growth factor binding protein-3 inhibits porcine grn in vitro. American Fournal of Physiology 268 E1057-E1064.

Schams D, Berisha B, Kosmann M, Einspanier R \& Amselgruber WM 1999 Possible role of growth hormone, IGFs, and IGF-binding proteins in the regulation of ovarian function in large farm animals. Domestic Animal Endocrinology 17 279-285.

Shemesh M 1979 Inhibitory action of follicular fluid on progesterone and prostaglandin synthesis in bovine follicles. Fournal of Endocrinology 82 27-31.

Shimasaki S, Koba A, Mercado M, Shimonaka M \& Ling A 1989 Complementary DNA structure of the high molecular weight rat insulin-like growth factor binding protein (IGFBP-3) and tissue distribution of its mRNA. Biochemical and Biophysical Research Communications 165 907-912.

Sirotkin A 1996 Direct action of growth hormone on bovine ovarian cells: effects on estradiol, oxytocin, vasopressin secretion by granulosa cells and on oocyte maturation and cleavage in vitro. Annales d'Endocrinologie 57 219-224.

Sirotkin AV \& Makarevich AV 1999 GH regulates secretory activity and apoptosis in cultured bovine granulosa cells through the activation of the cAMP/protein kinase A system. Fournal of Endocrinology 163 317-327.

Sirotkin A \& Nitray J 1994 Growth hormone and prolactin affect oxytocin, vasopressin, progesterone and cyclic nucleotide secretion by bovine granulosa cells in vitro. Fournal of Endocrinology 143 417-422.

Sirotkin AV, Makarevich AV, Kotwica J, Marnet P-G, Kwon HB \& Hetenyi L 1998 Isolated porcine ovarian follicles as a model for the study of hormone and growth factor action on ovarian secretory activity. Fournal of Endocrinology 159 313-321.

Spicer LJ \& Chamberlain CS 1999 Insulin-like growth factor binding protein-3: its biological effect on bovine granulosa cells. Domestic Animal Endocrinology 16 19-29.

Spicer LJ \& Echternkamp SE 1995 The ovarian insulin-like growth factor system with an emphasis on domestic animals. Domestic Animal Endocrinology 12 223-245.

Spicer LJ, Stewart RE, Alvarez P, Francisco CC \& Keefer BE 1997 Insulin-like growth factor-binding protein-2 and -3: their biological effects in bovine thecal cells. Biology of Reproduction 56 1458-1465.

Wandji SA, Wood TL, Crawford J, Levison SW \& Hammond JM 1998 Expression of mouse ovarian insulin growth factor systém components during follicular development and atresia. Endocrinology 139 5205-5214.

Wathes DC 1989 Oxytocin and vasopressin in the gonads. Oxford Reviews of Reproductive Biology 11 226-283.

Yoshimura Y 1998 Insulin-like growth factors and ovarian physiology. Fournal of Obstetrics and Gynaecology Research 24 305-323.

Yuan W, Bao B, Garverick HA, Youngquist RS \& Lucy MC 1998 Follicular dominance in cattle is associated with divergent patterns of ovarian gene expression for insulin-like growth factor (IGF)-I, IGF-II, and IGF binding protein-2 in dominant and subordinate follicles. Domestic Animal Endocrinology 15 55-63.

RECEIVED 31 May 2001

ACCEPTED 8 August 2001 